\title{
Revealing past and future land-cover transitions from 1985 to 2036 in the drylands of Central Iran
}

\author{
Bibizahra Mazloum ${ }^{1}$, Saied Pourmanafi ${ }^{1}$, Alireza Soffianian ${ }^{1}$, Abdolrassoul Mahini ${ }^{2}$, and \\ Alexander Prishchepov ${ }^{3}$ \\ ${ }^{1}$ Isfahan University of Technology \\ ${ }^{2}$ Gorgan University of Agricultural Sciences and Natural Resources \\ ${ }^{3}$ University of Copenhagen
}

April 29, 2020

\begin{abstract}
Land serves as a vital production resource, and therefore, land planning plays an important role in sustainable land-use design. Increasing the global population alters landscapes via land-use and land-cover change across different landscapes, including the drylands. Iran includes large areas of dryland, where the population increased by $60 \%$ from 1985 to 2016 . Further population increase in Iran would require more land resources to be allocated for human needs. However, the pace and patterns of these changes remain unclear. The aim of this study was to map land-cover change from 1985 to 2016 and predict future land-cover change in the Zayandehrood ecologic sub-basins of Central Iran. By using multiseasonal Landsat imagery, nine thematic classes were mapped with a random forest classifier for 1985, 1998, and 2016 with an overall accuracy of $80 \%$ for each period. Classification results revealed that from 1985 to 2016 residential areas doubled and industrial areas increased at the expense of rangelands. Our study also revealed cropland expansion at the expense of rangelands, cropland abandonment and contraction of croplands due to residential and industrial development. Prediction of changes by 2036 with a multi-layer perceptron neural network and Markov chain analysis revealed further expansion of industries and residencies particularly nearby the protected areas such as Ghamashlu Wildlife Refuge. Predicted contraction of some degraded agricultural lands and concomitant agricultural expansion in the agricultural frontier by 2036, underscore the importance of sustainable land management in highly arid areas of Iran and improvement of the strategies for the protection of rangelands.
\end{abstract}

\section{Revealing past and future land-cover transitions from 1985 to 2036 in the drylands of Central Iran}

Bibizahra Mazloum $^{1 *}$, Saied Pourmanafi ${ }^{1}$, Alireza Soffianian ${ }^{1}$ and Abdollrasoul Salman Mahini ${ }^{2}$, Alexander V. Prishchepov ${ }^{3}$

1. College of Natural Resources, Isfahan University of Technology, Iran

${ }^{2}$ Department of Environment, Gorgan University of Agricultural Sciences \& Natural Resources, Iran

${ }^{3}$ Department of Geosciences and Natural Resource Management (IGN), University of Copenhagen, Øster Voldgade 10, DK-1350 København K, Denmark

* Corresponding author: bibizahramazloum@gmail.com, phone: +4535331386

Abstract

Land serves as a vital production resource, and therefore, land planning plays an important role in sustainable land-use design. Increasing the global population alters landscapes via land-use and land-cover change across different landscapes, including the drylands. Iran includes large areas of dryland, where the population 
increased by $60 \%$ from 1985 to 2016 . Further population increase in Iran would require more land resources to be allocated for human needs. However, the pace and patterns of these changes remain unclear. The aim of this study was to map land-cover change from 1985 to 2016 and predict future land-cover change in the Zayandehrood ecologic sub-basins of Central Iran. By using multiseasonal Landsat imagery, nine thematic classes were mapped with a random forest classifier for 1985, 1998, and 2016 with an overall accuracy of $80 \%$ for each period. Classification results revealed that from 1985 to 2016 residential areas doubled and industrial areas increased at the expense of rangelands. Our study also revealed cropland expansion at the expense of rangelands, cropland abandonment and contraction of croplands due to residential and industrial development. Prediction of changes by 2036 with a multi-layer perceptron neural network and Markov chain analysis revealed further expansion of industries and residencies particularly nearby the protected areas such as Ghamashlu Wildlife Refuge. Predicted contraction of some degraded agricultural lands and concomitant agricultural expansion in the agricultural frontier by 2036, underscore the importance of sustainable land management in highly arid areas of Iran and improvement of the strategies for the protection of rangelands.

\section{Introduction}

Land serves as a vital production resource and therefore land planning plays an important role in sustainable land use design (Foley et al. , 2011; Lambin \& Meyfroidt, 2011). Human-induced land-use and land-cover change (LULCC) are the key proximate causes that shape landscapes at different scales (Foley, 2005; Lambin \& Geist, 2006). Evidence shows that LULCC increased over the last 100 years due to population growth, and subsequent increasing land demand and changing consumption patterns, among other factors (GerbensLeenes \& Nonhebel, 2005; Goldewijk, 2001). It is envisaged that the purpose of land planning is to direct the agents that change land use (e.g., landowners, farmers) to a point that results in the balance between meeting societal needs and protection of the environment. Hence, the quantitative assessment of the state of land cover and land use and revealing the potential changes of land cover is crucial for better sustainable land-use planning (Herrmann \& Osinski, 1999).

Earth observation, such as satellite remote sensing, is a prominent approach to monitor land changes and produce land-cover maps (Cohen \& Goward, 2004; Coppin et al. , 2004; Hansen \& Loveland, 2012). There has been substantive progress over the last three decades with the aid of remote sensing to monitor how humans appropriate land; for instance, the dynamic of residential and industrial areas (Reba \& Seto, 2020), agriculture and forestry activities (Eisavi et al. , 2015; Hansen et al. , 2013; Rufin et al. , 2019), and also the intensity of appropriation of rangelands (Dara et al. , 2020; Jakimow et al. , 2018), including drylands (Dubovyk, 2017). In the past, scientists have relied on field surveys and interpretation of aerial photographs to map LULCC, often over smaller areas (Nebikeret al. , 2014). As the size of the area of study becomes bigger, field surveys and interpretation of aerial photos become very costly and time-consuming. Therefore, satellite remote sensing is an excellent source of information to study LULCC at local and regional scales because satellite images, from on-board of Landsat satellites for instance, can cover a large extent and have a higher temporal coverage compared to field based observations and aerial surveys (Hansen \& Loveland, 2012; Loveland \& Dwyer, 2012). Landsat images from the freely accessible United States Geological Survey (U.S.G.S.) archive are used widely to evaluate the quantitative parameters of land, especially land use/cover change due to long historical repetitive coverage, the spatial resolution of Landsat images that match LULCC phenomena and relevant radiometric resolution suited to map vegetation change, including drylands and rangelands (Eisavi et al. , 2015; Ridwan et al. , 2018; Roy et al. , 2014). Moreover, the change of paradigm about free accessibility of Landsat records made this data relevant for the scientific community to monitor LULCC (Wulder et al. , 2012).

There has also been progress in the application of semi-automatic classification methods to derive thematic classes from satellite imagery and produce LULCC maps. Machine-learning algorithms gained popularity recently to classify satellite imagery due to the ability to handle non-linearity among spectrally complex classes, such as various urban landscapes, agriculture and rangelands (Dara et al. , 2020; Khatami et al. , 2016; Kraemer et al. , 2015; Löw et al. , 2015). Random forest, which is probably the most popular machinelearning classification method, is an ensemble classifier, where, instead of one single tree (CART and C4.5), 
multiple trees from training data are produced. Such an approach allows the model overfit to be reduced (Belgiu \& Drăguţ, 2016; Gislason et al. , 2006). At the same, compared to CART no pruning of produced trees is implemented in a random forest, which allows increasing classification accuracy with random forest (Belgiu \& Drăgut,, 2016; Gislason et al. , 2006). High precision, ability to learn nonlinear relationships, ability to determine variables, non-parametric nature, high computation speed, and resistance to over-fitting are among the advantages of random forest classifier (Belgiu \& Drăguţ, 2016; Gislason et al. , 2006; Millard \& Richardson, 2015). It has been also noted, classification error decreases by increasing the number of trees; both the number of trees and the number of utilized variables for branches of each node can be parameterized (Belgiu \& Drăguţ, 2016; Gislason et al. , 2006). The random forest classifier has been widely used over the last two decades for land-change mapping (Chen et al. , 2019; Jakimowet al. , 2018; Millard \& Richardson, 2015). In sum, a random forest classifier can be a promising classifier to map LULCC in spectrally complex areas, such as the drylands of Iran (Eisavi et al. , 2015).

Various models have been used for investigating the dynamics of land use and predicting the land-use changes in order to improve decision-making (Castella \& Verburg, 2007; Verburg et al. , 2006; Zhang et al. , 2015). Some models, especially dynamic models such as Markov, dynamic systems, automatic cells, multi-agent models, and conversion of land use and its effects at small regional extent (CLUE-S), can help the decisionmakers to evaluate potential land-cover change patterns under the different scenarios (Mallampalli et al. , 2016; Sun et al. , 2016; Verburg et al. , 2002). Each of these models has advantages and disadvantages for predicting land-cover change. For instance, geometry modification technology (GEOMOD) can model only two land-cover change classes (Pontius Jr \& Chen, 2006) and SLEUTH (slope, land use, exclusion, urban extent, transportation and hillshade) is primarily used for urban development and cannot capture the driving forces behind urban growth. Additionally, SLEUTH has limitations on the number of input variables and can be implemented only under the UNIX system (Chaudhuri \& Clarke, 2013; Sekovski et al. , 2015). SLEUTH is deliberately focused more on form and dynamics, i.e., "where" could the development take place, but not "why" (e.g., demography and socioeconomic processes) (Sekovski et al. , 2015).

Land Change Modeler, available via Terrset software (former Idrisi software, Clark Labs) (Eastman, 2015), can model multiple land-cover change trajectories simultaneously in comparison to the above methods and tools. One of its advantages is that it is available via Terrset and can be run with Windows operating system, therefore it is more available for a broader community. It has no limitation on the number of input variables. It provides more capabilities for tuning than other methods, in addition to its simplicity. Land Change Modeler has been used to evaluate and model various land-cover changes in Iran (Ansari \& Golabi, 2019).

Unsustainable land-use activities may result in substantial negative ecological consequences with cascade effects even when land-use change occurs at the local level (Newbold et al. , 2015; Yaghobi et al. , 2019). Reduction of the negative environmental impacts of land-use change while maintaining economic viability and social acceptability is a particular challenge for most developing countries in Asia, including Iran (Zhao et al. , 2006). For instance, in Iran, the population increased by $60 \%$ from 50 million to 80 million people just within a 30-year course from 1986 to 2016 (Danaei et al. , 2019). Over the same course, the urban population increased and by 2016, it comprised 70\% (Danaei et al. , 2019). Most of the territory of Iran can be considered dryland with vast rangelands and irrigated croplands lying in semi-desert conditions (Mesgaran et al. , 2017; The Cambridge History of Iran , 1968). There has been documented evidence of environmental degradation caused by unsustainable urban and agricultural expansion (Minaei et al. , 2018; Yaghobi et al. , 2019; Zareie et al. , 2016). This all increased the concern of the scientific community on the negative impact on the environment and the relevance of quantification and prediction of such impacts.

The ultimate goal of this study was to assess land-cover change with the aid of multiseasonal Landsat satellite imagery from 1985 to 2016 in Zayandehrood ecologic sub-basins of Central Iran, an area of rapid agricultural and urban/industrial development and to determine the required land amount for various land uses in the future. Our specific research questions were:

1. What are the major trajectories of land-cover change in Zayandehrood ecologic sub-basins of Central 
Iran from 1985 to $2016 ?$

2. What will be the future land-cover/ use transitions in the study area by 2036 ?

Methods

\subsection{Study area}

The study area includes the three sub-basins of Zayandehrood: Lanjanat, Najafabad, and Mahyar Shomali, which are located at $5057^{\prime}$ to $5151^{\prime}$ of eastern longitude and $3145^{\prime}$ to $3250^{\prime}$ of northern latitude with an area of 527,148 hectares in the Isfahan province of Iran (figure 1).

The population in the study area increased from 321,000 in 1996 to 2.26 million people in 2016 (https://www.isfahan.irib.ir). The climate ranges from arid and semi-arid (east and southeast) to cold semi-humid (west and southwest) with an elevation range from 1,569 m (plains, hills) to 3,235 m (mountains). Rainfall increases with elevation, while temperature decreases. The mean annual temperature is $13{ }^{\circ} \mathrm{C}$, and the mean annual rainfall is 209 $\mathrm{mm}$. The Zayandehrood River is the biggest and most important river in the study site, which originates in the Zagros Mountains (figure 1). This river provides water for farming, residential areas and industries in the study site and finally goes to the Gavkhoni wetland in the east of the watershed (Akbari et al. , 2015; Iranmehr et al. , 2015). The Ghamashlu National Park in the north and Kola Ghazi National Park in the Southeast host charismatic herbivores, Capra aegagrus and Gazella subgutturosa. Among protected native plants in the study area are Fritillaria imperialis and Pistacia atlantica. Therefore, despite semi-arid conditions, the study area has high biodiversity and importance for environmental protection. Different land uses, such as residential areas, agriculture, industries and mining, emphasize the importance of obtaining accurate information about the state of land use and of developing strategies for sustainable land use in the future.

$<$ Figure $1>$

\subsection{Data}

In this study, U.S.G.S. Landsat multiseasonal imagery for the years circa 1985, 1998, and 2016 were used to match the development of land-planning policy over the last decades in Iran. Landsat images are well-suited to distinguish different land-cover types due to the spectral and spatial resolution of the sensors (TM, ETM+, OLI) on board Landsat satellites, and also due to the temporal revisits. To determine different phonological stages of spring and summer crops, image-dates for May and August were selected. Systematically corrected (topography and atmosphere) level 2 Landsat imagery from TM and OLI sensors were acquired from U.S.G.S. for Word Reference System -2 (WRS-2) path 37 and 38 and row 164. We then mosaicked satellite imagery from different paths.

\subsection{Classification with random forest classifier}

Image classification is a method for extracting environmental parameters, such as land cover and land use (LCLU) (Jensen, 2004). An expert who conducts a supervised classification should have prior knowledge about study area conditions and land uses. For this study, training samples were determined by using available maps, aerial images, field data and ancillary spatial information, such as soil types. We used a random forest classifier implemented in the package "random Forest" in statistical R software. Based on the literature and preliminary tests, we used 1,000 trees to parameterize the random forest classifier. We used the Blue, Green, Red, NIR, SWIR-1, and SWIR-2 bands for Landsat 4, 5 TM, Landsat 7 ETM + and Landsat 8 OLI to produce LCLU change maps with a random forest classifier. The iterative classification approach was used with an increase of training samples selected for each thematic class until the classification accuracy for individual thematic classes did not increase anymore.

We developed a classification catalog, which presented a mix of LCLU classes (Table 1). Our classification catalog consisted of eight thematic classes: 'forest', 'agriculture', 'rangeland', 'water', 'rocks', 'industry', 'residences', and 'other'. The 'forest' class consisted of urban and industrial green space with trees and tree plantations, 'agriculture' consisted of tilled agricultural land used for crops and clean or green fallow land as 
a part of crop rotation. The 'rangeland' class consisted of native natural plants with low (type I) to medium (type II) density. 'Water' represented water objects, such as rivers, natural wetlands and man-made water ponds. The 'rock 'class consisted of rocky outcrops and the mountains. 'Industry' consisted of industrial areas and mines. 'residences' comprised urban and rural settlements and main paved roads and the 'other' class was bare soil, industrial and mineral wastelands, and dirt roads.

$<$ Table $1>$

2.4 Field data collection for parameterization of the classifier and accuracy assessment

Field data, which was later utilized for training and accuracy assessment, was collected following several steps. Field campaigns were conducted and information about land-cover types was recorded with a nondifferential GPS during May and August 2016. Notes were also taken on land-cover and land-use types. For a better interpretation of the results, photos were taken in the field as well. We also interviewed the farmers about their activities to reconstruct land use by recalling memories about land use, back to 1985 . Field-collected data were then used to parameterize and correct the random forest classifier, and assess the classification accuracy of produced maps. We showed satellite imagery available via Google Earth mapping services during the interviews with farmers if we were not sure about the type of LCLU.

\subsection{Post-classification change detection}

The process of LCLU change determination is attributed to change detection over time (Coppin et al. , 2004; Lu et al. , 2004). A post-classification change detection approach was used to assess land transitions from 1985 to 1998 and 2016. More specifically, five trajectories were assessed in more detail: "rangeland to residences", "rangeland to forest", "agriculture to residences", "rangeland to agriculture", and "rangeland to industry".

\subsection{Accuracy assessment of classified land-cover/ use maps}

The accuracy of produced maps was examined quantitatively with validation data produced by visual expert interpretation of multiseasonal Landsat imagery, high-resolution satellite imagery available via Google Earth $^{\mathrm{TM}}$ mapping service and the use of field-collected data. Accuracy assessment was performed for 1985, 1998 and 2016 maps. In total, 1,277 points were used to evaluate the accuracy of the thematic maps, which were produced with a stratified random sampling approach. Overall, producer's and user's accuracies were calculated based on contingency tables between validation data and classified maps.

\subsection{Prediction of land cover/ use change}

Land cover/ use change can be determined by biophysical, technological, economic, social and political drivers but also by trigger events (Bürgiet al., 2004; Geist \& Lambin, 2002; Hersperger et al. , 2010). Here we used biophysical site conditions to predict the spatial characteristics of LCLU change from 1985 to 2016 with the Terrset Land Change Modeler, where we developed several sub-models. Based on potential transition scenarios, following "business-as-usual" namely, rangeland to other land uses and agriculture to residences, time-dependent (dynamic) and time-independent (static) descriptive variables were determined in order to assess the transition potentials of pixels of one land use/cover to another (De Rosa et al. , 2016). Cramer coefficient, which ranges from "0" (no correlation) to " 1 " (strong correlation), was used to determine the correlation of model variables (independent variables) with LCLU classes (dependent variables). The prediction of LCLU transition was made separately for five transition classes, namely "rangeland to residences", "rangeland to forest", "agriculture to residences", "rangeland to agriculture", and "rangeland to industry". LCLU change was predicted for 2016 and 2036 with a multi-layer perceptron (MLP) neural network. To determine the amount of change that will occur up to 2036, we used the Markov chain prediction process.

Several spatial biophysical and socioeconomic variables, namely, distance to water, residences, industries, agriculture and rangelands (based on classification results for 1985 and 2016), slope, distance to roads and flood potential, determined the likelihood of LCLU change transitions (figure 6). The slope was calculated based on a 30-meter shuttle radar topography mission (SRTM) digital elevation model (DEM) (figure 6). The 
Euclidian distance to roads was calculated based on the digital map of main roads. Similarly, the Euclidian distance to water was calculated with the account of the Zayandehrood River and the main water channels. We also assessed the susceptibility to floods (flood potential), which was determined based on the calculation of the distances to seasonal and permanent water flows based on hydrologic maps for the study area. All produced maps were calculated with a 30 -meter pixel size to match the LULCC maps.

Results

\subsection{Land use/cover classification and accuracy assessment}

Our classified land-cover maps for 1985, 1998, and 2016 consisted of 'rocks', 'rangeland type I', 'rangeland type II', 'water', 'agriculture', 'residences', 'forest', 'industry' and 'other' thematic classes, and were produced with plausible classification accuracies (figure 2, Table 2). To increase the accuracy for the 'agriculture' class, lands with clean and green fallow, tilled soil and lands under crops were combined. To increase the accuracy of the 'residences' class, post-classification assessment was performed with a reverse comparison of the residences' patterns; if they first appeared in 1985, they should also appear in the 1998 and 2016 maps (the assumption being that there was no reduction in residential area over time).

\section{$<$ Figure 2>}

Table 2 shows the accuracy of maps and classes produced with a random forest classifier. The 'agriculture' thematic class had a high accuracy in all years. The accuracies for the 'rangeland type I', and 'forest' thematic classes were high as well. The user's and producer's accuracies for the 'residences' class varied from 0.67 to 0.80. The classes 'rocks', 'other', and 'rangeland type I' were the least accurate ones due to low spectral separability among these classes.

$<$ Table $2>$

\subsection{Land use/cover change detection}

Results showed that the 'water' and 'rocks' thematic classes had a negligible decrease during the studied period. The 'water' thematic class, which included rivers, water channels and big man-made pools, might exhibit inter-annual change due to fluctuation of precipitation levels for the three studied periods (figure 3). The presence of snow in one of the images for 1998 could affect the extent of the 'rangeland type II' thematic class. 'Industry', 'forest', 'residences' and 'agriculture' thematic classes increased from 1985 to 2016, while the 'rangeland type I' thematic class steadily decreased (figure 4). From 1985 to 2016, the 'forest' thematic class increased ten times, the 'industry' thematic class three times, and the 'residences' class two times.

\section{$<$ Figure $3>$}

$<$ Figure $4>$

A detailed visual inspection of classified maps revealed that the 'agriculture' thematic class expanded mostly at the expense of the 'rangeland type I' thematic class, with 3.3\% growth in area from 1985 to 2016 (table 2 , table 3). Visual qualitative inspection of land use/cover change also revealed forests and urban greenery that had been planted mainly around the industries and mines from 1985 to 2016 (figure 5). Spatial growth of residential areas from 1985 to 2016 primarily occurred at the expense of agricultural lands, 'rangeland type I', and in close proximity to existing residential areas and roads (figure 5).

$<$ Table $3>$

$<$ Figure $5>$

Results also showed that the conversion of 'agriculture' to 'residences' and 'forest' was more pronounced from 1998 to 2016 than from 1985 to 1998, which was different for the transition from 'rangeland type I' to 'industry' (which dominated from 1985 to 1998).

\subsection{Land-cover/ use change prediction}


By using the VALIDATE method in the Terrset GIS software, agreement was measured between predicted maps and the classified map for 2016. The Standard Kappa Index, Quality Kappa Index (no location), and Location Kappa Index for 2016 model validation were 0.91, 0.92, and 0.93, respectively (table 4). The accuracy of the predicted map for 2016 was $88 \%$.

The predicted LULCC map from 2016 to 2036 revealed multiple trajectories of land transformation, such as an increase of some classes often at the expense of rangeland type I. For instance, 'residences' should increase to 9000 (ha) at the expense of class 'agriculture' and 'rangeland type I' (figure 7, 8).

\section{$<$ Table $4>$ \\ $<$ Figure $6>$ \\ $<$ Figure $7>$ \\ $<$ Figure 8> \\ Discussion}

Land-cover/use change has various implications for the environment (De Rosa et al. , 2016). LULCC prediction models provide the possibility to assess the change of land cover and land use and supply important information for better land-use planning to managers and stakeholders (Ansari \& Golabi, 2019; Herrmann \& Osinski, 1999). Often, watersheds are considered as an important assessment unit for land planning. Therefore, we determined our study area based on the ecologic border of the Lenjan and Najafabad watersheds of the Zayandehrood River to prepare a suitable estimation of the spatial transition potential of the land. The study area is within the province administrative units and the results of the study can be used for the development of land management plans.

We reconstructed land cover/ use change with multiseasonal Landsat imagery for 1985, 1998 and 2016 for the watershed surrounding the Zayandehrood River, which is the main water resource of the study area and our study revealed multiple trajectories of land change. For instance, our study showed both agricultural expansion, but also abandonment (an increase of fallow and completely abandoned areas from 1985 to 2016). Several studies suggested that human factors, such as over-using underground water resources, and water transfer plans are the main reasons for water decrease including the Zayandehrood River and, consequently, resulting in abandonment of agriculture plots where irrigation and production costs on degraded lands are not compensated by the returns from farming (Azadi et al., 2016; Fazli, A \& Badi, Sh, 2017; Minaei et al. , 2018). Therefore, the current water management plans are not sustainable as they result in exhausting water resources and salinization of some plots as in other parts of Iran (Iranmehr et al. , 2015; Yaghobi et al. , 2019; Zeaieanet al. , 2005).

Our classification results also revealed the conversion of agricultural lands to residences and recreational and industrial areas in close proximity to residential areas, in drought-prone areas, and with deficient water resources. These findings were in line with earlier studies in other parts of Iran, which also found a contraction of agricultural lands in proximity to residential areas (Eisavi et al., 2015; Mosammam et al. , 2017; Soffianian \& Madanian, 2015). Such finds are worrisome because Iran also relies on food imports. Any additional contractions of croplands in Iran may pose a threat for food insecurity.

Our findings also showed that residential areas and even new industrial towns such as Majlesi were built at the expense of the rangelands. Contrary to the contraction of agricultural lands in the vicinity of residential areas, we also observed an increase in agricultural land at the expense of rangelands. Rangelands that were not converted to croplands, were often left at the marginal areas. Thus, any new cropland expansion at the expense of rangelands suggested cropland encroachments in agro-environmental frontiers with unstable yields and in areas prone to abandonment (Kraemer et al., 2015; Yaghobi et al. , 2019). Rangelands in many parts of the world, including Iran, have a weak protective status. At the same time, rangelands host charismatic umbrella species and support the livelihoods in rural areas, including rangeland livestock herding (Behnke et al. , 2016; Dara et al. , 2020; Kerven et al. , 2006). Therefore, the permanent conversion of rangelands 
to industrial areas should be controlled, and zoning should be developed to avoid the unintended land conversions and reduction of valuable ecosystem services rangelands provide (Gudkaet al. , 2014; Kamp et al. , 2015). With the current land management policies and prediction of land-change we provide, the protected areas, especially Ghamashlu Wildlife Refuge, in our study area (figure 8) are at risk. For instance, our study revealed ongoing residential expansion in proximity to the Wildlife Refuge.

The presence of mineral sources in our study area, particularly in the mountains, resulted in the expansion of opened-cast mining, thus creating conflicts with environmental preservation strategies. Our land-change predictions and evaluation of existing plans about mining suggest further continuation of the negative impact of mining and supplementary road construction on rangelands and other drylands (Madadiet al., 2014; Makki et al. , 2012). Expansion of big industrial towns and various mines over the last 30 years has also intervened between natural resource management and exploitation of water resources with other land uses such as farming (Soffianian \& Madanian, 2015). Given a shortage of water resources in the study region of Iran, a vicious circle between the expansion of various land-use practices and water resources may result in further contraction of valuable land resources, and therefore, our results are extremely relevant for better land-use planning in the drylands of Iran.

In this study, we evaluated land-cover changes starting from 1985 to 2016. Land-change transformations started much earlier than our first year of observation (1985), for instance following the change of the political and institutional course in Iran in 1978. However, we captured an overall course of post-1978 land-cover change driven by the aim of satisfying the needs of the growing population. Before 1985, Landsat satellite imagery were scattered (Landsat 4 and $5 \mathrm{TM}$ ) or came with coarser spatial and radiometric resolution (Landsat 1-3 MSS). Similarly, we made projections about land-cover change by 2036 based on the overall course of land transformation in the past, therefore reflecting the "business-as-usual" scenario. There might be other counterfactual scenarios that may mediate the rates and patterns of land-cover change, such as adjustment of existing land-use policies (Mallampalli et al. , 2016; Prishchepov et al. , 2019), change of economic conditions in Iran, etc. However, our projection can be used as a starting point of evaluation of existing policies and additional counterfactual scenarios can be built around.

Our study showed multiple pathways of land transformations in the dryland of central Iran, for instance, when both cropland expansion and abandonment concomitantly are taking place and go hand in hand with urban sprawl at the expense of rangelands. Despite the extreme climatic conditions, global drylands, which occupy almost half of the global surface (Prăvălie, 2016), are experiencing rapid land transformation due to the overall population increase. Moreover, a large portion of drylands are in developing countries, such as Iran, where livelihoods strongly depend on agriculture and environmental goods (Brandt et al. , 2017; Emg, 2011; Tong et al. , 2017). Despite a growing population across dryland, both cropland expansion and abandonment have also been found in other parts of the drylands of Northern Eurasia, such as Kazakhstan (Chen et al. , 2013; Horion et al. , 2016; Löwet al. , 2015), Mongolia (Dong et al., 2011; Jamsranjavet al. , 2018; Sankey et al. , 2018) and Uzbekistan (Dubovyket al. , 2012). Considering the adverse climatic projections that drylands of Eurasia will face during the $21^{\text {st }}$ century (Groisman et al. , 2017; Groisman \& Soja, 2009), better land-use policies should be developed toward sustainable use of land and water resources to satisfy predicted population growth.

Acknowledgements

Authors thank DFF-Danish ERC Support Program (grant number: 116491, 9127-00001B) and the University of Copenhagen for a six month research stay at the University of Copenhagen, Department of Geosciences and Natural Resource Management (IGN).

\section{References}

Akbari N, Niksokhan MH, Ardesani M. 2015. Optimization of water allocation using cooperative game theory (Case study: Zayandehrud basin). Journal of Environmental Studies 40 : 875-890 and 10

Ansari A, Golabi MH. 2019. Prediction of spatial land use changes based on LCM in a GIS environment 
for Desert Wetlands - A case study: Meighan Wetland, Iran. International Soil and Water Conservation Research 7 : 64-70. DOI: 10.1016/j.iswcr.2018.10.001

Azadi H, Barati AA, Rafiaani P, Raufirad V, Zarafshani K, Mamoorian M, Van Passel S, Lebailly P. 2016. Agricultural Land Conversion Drivers in Northeast Iran: Application of Structural Equation Model. Applied Spatial Analysis and Policy 9 : 591-609. DOI: 10.1007/s12061-015-9160-4

Behnke R, Robinson S, Milner-Gulland EJ. 2016. Governing open access: livestock distributions and institutional control in the Karakum Desert of Turkmenistan. Land Use Policy 52 : 103-119. DOI: 10.1016/j.landusepol.2015.12.012

Belgiu M, Drăgut L. 2016. Random forest in remote sensing: A review of applications and future directions. ISPRS Journal of Photogrammetry and Remote Sensing 114 : 24-31. DOI: 10.1016/j.isprsjprs.2016.01.011

Brandt M, Rasmussen K, Peñuelas J, Tian F, Schurgers G, Verger A, Mertz O, Palmer JRB, Fensholt R. 2017. Human population growth offsets climate-driven increase in woody vegetation in sub-Saharan Africa. Nature Ecology \&3 Evolution 1 . DOI: 10.1038/s41559-017-0081

Bürgi M, Hersperger A, Schneeberger N. 2004. Driving forces of landscape change - current and new directions. Landscape Ecology 19 : 857-868

Castella J-C, Verburg PH. 2007. Combination of process-oriented and pattern-oriented models of land-use change in a mountain area of Vietnam. Ecological Modelling 202 : 410-420

Chaudhuri G, Clarke K. 2013. The SLEUTH land use change model: A review.International Journal Of Environmental Resource Research1 : 88-105

Chen T-HK, Prishchepov AV, Fensholt R, Sabel CE. 2019. Detecting and monitoring long-term landslides in urbanized areas with nighttime light data and multi-seasonal Landsat imagery across Taiwan from 1998 to 2017.Remote Sensing of Environment 225 : 317-327. DOI: 10.1016/j.rse.2019.03.013

Chen X, Bai J, Li X, Luo G, Li J, Li BL. 2013. Changes in land use/land cover and ecosystem services in Central Asia during 1990-2009. Current Opinion in Environmental Sustainability 5 : 116-127. DOI: 10.1016/j.cosust.2012.12.005

Cohen WB, Goward SN. 2004. Landsat's Role in Ecological Applications of Remote Sensing. BioScience 54 : 535. DOI: 10.1641/0006-3568(2004)054[0535:LRIEAO]2.0.CO;2

Coppin P, Jonckheere I, Nackaerts K, Muys B, Lambin E. 2004. Digital change detection methods in ecosystem monitoring: A review.International Journal of Remote Sensing 25 : 1565-1596. DOI: 10.1080/0143116031000101675

Danaei G, Farzadfar F, Kelishadi R, Rashidian A, Rouhani OM, Ahmadnia S, Ahmadvand A, Arabi M, Ardalan A, Arhami M, Azizi MH, Bahadori M, Baumgartner J, Beheshtian A, Djalalinia S, Doshmangir L, Haghdoost AA, Haghshenas R, Hosseinpoor AR, Islami F, Kamangar F, Khalili D, Madani K, MasoumiAsl H, Mazyaki A, Mirchi A, Moradi E, Nayernouri T, Niemeier D, Omidvari A-H, Peykari N, Pishgar F, Qorbani M, Rahimi K, Rahimi-Movaghar A, Tehrani FR, Rezaei N, Shahraz S, Takian A, Tootee A, Ezzati M, Jamshidi HR, Larijani B, Majdzadeh R, Malekzadeh R. 2019. Iran in transition. The Lancet 393 : 1984-2005. DOI: 10.1016/S0140-6736(18)33197-0

Dara A, Baumann M, Freitag M, Hölzel N, Hostert P, Kamp J, Müller D, Prishchepov AV, Kuemmerle T. 2020. Annual Landsat time series reveal post-Soviet changes in grazing pressure. Remote Sensing of Environment 239 : 111667. DOI: 10.1016/j.rse.2020.111667

De Rosa M, Knudsen MT, Hermansen JE. 2016. A comparison of Land Use Change models: challenges and future developments. Journal of Cleaner Production 113 : 183-193. DOI: 10.1016/j.jclepro.2015.11.097

Dong J, Liu J, Yan H, Tao F, Kuang W. 2011. Spatio-temporal pattern and rationality of land reclamation and cropland abandonment in mid-eastern Inner Mongolia of China in 1990-2005. Environmental Monitoring and Assessment 179 : 137-153. DOI: 10.1007/s10661-010-1724-9 
Dubovyk O. 2017. The role of Remote Sensing in land degradation assessments: opportunities and challenges. European Journal of Remote Sensing 50 : 601-613. DOI: 10.1080/22797254.2017.1378926

Dubovyk O, Menz G, Conrad C, Kan E, Machwitz M, Khamzina A. 2012. Spatio-temporal analyses of cropland degradation in the irrigated lowlands of Uzbekistan using remote-sensing and logistic regression modeling. Environmental Monitoring and Assessment . DOI: 10.1007/s10661-012-2904-6

Eastman J. 2015. TerrSet: Geospatial monitoring and modeling software.

Clark Labs, Clark University

Eisavi V, Homayouni S, Yazdi AM, Alimohammadi A. 2015. Land cover mapping based on random forest classification of multitemporal spectral and thermal images. Environmental Monitoring and Assessment187 : 291. DOI: $10.1007 / \mathrm{s} 10661-015-4489-3$

Emg U. 2011. Global drylands: a UN system-wide response.

Environment Management Group of the United Nations Geneva. Retrieved from http://www. unccd. int/Lists/SiteDocumentL brary/Publications/Global_Drylands_Full_Report. pdf

Fazli, A, Badi, Sh. 2017. An Analysis of the Relationship between Instability of Agricultural Water Resources and Rural Development (Case Study: Rural Settlements of Zayandeh-Rud Basin Downstream).Journal of Research and Rural Planning 6 . DOI: 10.22067/jrrp.v5i4.60596

Foley JA. 2005. Global Consequences of Land Use. Science309 : 570-574. DOI: 10.1126/science.1111772

Foley JA, Ramankutty N, Brauman KA, Cassidy ES, Gerber JS, Johnston M, Mueller ND, O'Connell C, Ray DK, West PC, Balzer C, Bennett EM, Carpenter SR, Hill J, Monfreda C, Polasky S, Rockström J, Sheehan J, Siebert S, Tilman D, Zaks, D. P. M. 2011. Solutions for a cultivated planet. Nature 478 : 337-342. DOI: $10.1038 /$ nature 10452

Geist HJ, Lambin EF. 2002. Proximate Causes and Underlying Driving Forces of Tropical Deforestation. Bioscience 52 : 143-150

Gerbens-Leenes W, Nonhebel S. 2005. Food and land use. The influence of consumption patterns on the use of agricultural resources. Appetite 45 : 24-31. DOI: 10.1016/j.appet.2005.01.011

Gislason PO, Benediktsson JA, Sveinsson JR. 2006. Random Forests for land cover classification. Pattern Recognition Letters 27 : 294-300. DOI: 10.1016/j.patrec.2005.08.011

Goldewijk KK. 2001. Estimating global land use change over the past 300 years: The HYDE database. Global Biogeochemical Cycles15 : 417-433. DOI: 10.1029/1999GB001232

Groisman P, Shugart H, Kicklighter D, Henebry G, Tchebakova N, Maksyutov S, Monier E, Gutman G, Gulev S, Qi J, Prishchepov A, Kukavskaya E, Porfiriev B, Shiklomanov A, Loboda T, Shiklomanov N, Nghiem S, Bergen K, Albrechtová J, Chen J, Shahgedanova M, Shvidenko A, Speranskaya N, Soja A, de Beurs K, Bulygina O, McCarty J, Zhuang Q, Zolina O. 2017. Northern Eurasia Future Initiative (NEFI): facing the challenges and pathways of global change in the twenty-first century. Progress in Earth and Planetary Science 4 : 41. DOI: $10.1186 / \mathrm{s} 40645-017-0154-5$

Groisman P, Soja AJ. 2009. Ongoing climatic change in Northern Eurasia: justification for expedient research. Environmental Research Letters 4 : 045002. DOI: 10.1088/1748-9326/4/4/045002

Gudka M, Davies J, Poulsen L, Schulte-Herbrüggen B, MacKinnon K, Crawhall N, Henwood WD, Dudley N, Smith J. 2014. Conserving dryland biodiversity: a future vision of sustainable dryland development. Biodiversity 15 : 143-147. DOI: 10.1080/14888386.2014.930716

Hansen MC, Loveland TR. 2012. A review of large area monitoring of land cover change using Landsat data. Remote Sensing of Environment122 : 66-74. DOI: 10.1016/j.rse.2011.08.024 
Hansen MC, Potapov PV, Moore R, Hancher M, Turubanova SA, Tyukavina A, Thau D, Stehman SV, Goetz SJ, Loveland TR, Kommareddy A, Egorov A, Chini L, Justice CO, Townshend JRG. 2013. High-Resolution Global Maps of 21st-Century Forest Cover Change. Science 342 : 850-853. DOI: 10.1126/science.1244693

Herrmann S, Osinski E. 1999. Planning sustainable land use in rural areas at different spatial levels using GIS and modelling tools.Landscape and urban planning 46 : 93-101

Hersperger A, Gennaio M, Verburg P, Bürgi M. 2010. Linking Land Change with Driving Forces and Actors: Four Conceptual Models. Ecology and Society $15: 1-17$

Horion S, Prishchepov AV, Verbesselt J, de Beurs K, Tagesson T, Fensholt R. 2016. Revealing turning points in ecosystem functioning over the Northern Eurasian agricultural frontier. Global Change Biology 22 : 2801-2817. DOI: $10.1111 /$ gcb.13267

Iranmehr M, Pourmanafi S, Soffianian A. 2015. Ecological Monitoring and Assessment of Spatial-Temporal Changes in Land Cover with an Emphasis on Agricultural Water Consumption in Zayandeh Rood Region. Iranian Journal of Ecohydrology 2 . DOI: 10.22059/ije.2015.55126

Jakimow B, Griffiths P, van der Linden S, Hostert P. 2018. Mapping pasture management in the Brazilian Amazon from dense Landsat time series. Remote Sensing of Environment 205 : 453-468. DOI: 10.1016/j.rse.2017.10.009

Jamsranjav C, Reid RS, Fernández-Giménez ME, Tsevlee A, Yadamsuren B, Heiner M. 2018. Applying a dryland degradation framework for rangelands: the case of Mongolia. Ecological Applications 28 : 622-642. DOI: $10.1002 /$ eap.1684

Jensen JR. 2004. Introductory Digital Image Processing . Prentice Hall: Upper Saddle River, N.J

Kamp J, Urazaliev R, Balmford A, Donald PF, Green RE, Lamb AJ, Phalan B. 2015. Agricultural development and the conservation of avian biodiversity on the Eurasian steppes: a comparison of land-sparing and land-sharing approaches. Journal of Applied Ecology 52 : 1578-1587. DOI: 10.1111/1365-2664.12527

Kerven C, Alimaev I, Behnke R, Davidson G, Malmakov N, Smailov A, Wright I. 2006. Fragmenting Pastoral Mobility: Changing Grazing Patterns in Post-Soviet Kazakhstan. USDA Forest Service - Proceedings RMRSP-39

Khatami R, Mountrakis G, Stehman SV. 2016. A meta-analysis of remote sensing research on supervised pixel-based land-cover image classification processes: General guidelines for practitioners and future research. Remote Sensing of Environment 177 : 89-100. DOI: 10.1016/j.rse.2016.02.028

Kraemer R, Prishchepov AV, Müller D, Kuemmerle T, Radeloff VC, Andrey Dara, Terekhov A, Frühauf M. 2015. Long-term agricultural land-cover change and potential for cropland expansion in the former Virgin Lands area of Kazakhstan. Environmental Research Letters 10 : 054012

Lambin EF, Geist HJ. 2006. Land-Use and Land-Cover Change: Local Processes and Global Impacts (Global Change - The IGBP Series). SPRINGER

Lambin EF, Meyfroidt P. 2011. Global land use change, economic globalization, and the looming land scarcity. Proceedings of the National Academy of Sciences of the United States of America108:3465-3472. DOI: $10.1073 /$ pnas. 1100480108

Loveland TR, Dwyer JL. 2012. Landsat: Building a strong future.Remote Sensing of Environment 122 : 22-29. DOI: $10.1016 /$ j.rse.2011.09.022

Löw F, Fliemann E, Abdullaev I, Conrad C, Lamers JPA. 2015. Mapping abandoned agricultural land in Kyzyl-Orda, Kazakhstan using satellite remote sensing. Applied Geography 62 : 377-390. DOI: 10.1016/j.apgeog.2015.05.009

Lu D, Mausel P, Brondízio E, Moran E. 2004. Change detection techniques.International Journal of Remote Sensing 25 : 2365-2401. DOI: 10.1080/0143116031000139863 
Madadi H, Moradi H, Fakheran S, Jokar M, Makki T. 2014. Modeling the Propagation of Noise Pollution from Isfahan's West Ringway in Ghamishloo Wildlife Refuge Using SPreAD-GIS. Iranian Journal of Applied Ecology 3

Makki T, Fakheran S, Moradi H, Iravani M, Farahmand M. 2012. Ecological Impact Assessment of Isfahan's West Freeway on Ghamishloo Wildlife Refuge Using Habitat Evaluation Procedure (HEP). Iranian Journal of Applied Ecology 1

Mallampalli VR, Mavrommati G, Thompson J, Duveneck M, Meyer S, Ligmann-Zielinska A, Druschke CG, Hychka K, Kenney MA, Kok K, Borsuk ME. 2016. Methods for translating narrative scenarios into quantitative assessments of land use change. Environmental Modelling \& Software 82 : 7-20. DOI: $10.1016 /$ j.envsoft.2016.04.011

Mesgaran MB, Madani K, Hashemi H, Azadi P. 2017. Iran's Land Suitability for Agriculture. Scientific Reports 7 : 7670. DOI: 10.1038/s41598-017-08066-y

Millard K, Richardson M. 2015. On the Importance of Training Data Sample Selection in Random Forest Image Classification: A Case Study in Peatland Ecosystem Mapping. Remote Sensing 7 : 8489-8515. DOI: $10.3390 /$ rs70708489

Minaei M, Shafizadeh-Moghadam H, Tayyebi A. 2018. Spatiotemporal nexus between the pattern of land degradation and land cover dynamics in Iran.Land Degradation 83 Development 29 : 2854-2863. DOI: $10.1002 /$ ldr. 3007

Mosammam HM, Nia JT, Khani H, Teymouri A, Kazemi M. 2017. Monitoring land use change and measuring urban sprawl based on its spatial forms. The Egyptian Journal of Remote Sensing and Space Science 20 : 103116. DOI: $10.1016 /$ j.ejrs.2016.08.002

Nebiker S, Lack N, Deuber M. 2014. Building Change Detection from Historical Aerial Photographs Using Dense Image Matching and Object-Based Image Analysis. Remote Sensing 6 : 8310-8336. DOI: 10.3390/rs6098310

Newbold T, Hudson LN, Hill SLL, Contu S, Lysenko I, Senior RA, Börger L, Bennett DJ, Choimes A, Collen B, Day J, De Palma A, Díaz S, Echeverria-Londoño S, Edgar MJ, Feldman A, Garon M, Harrison MLK, Alhusseini T, Ingram DJ, Itescu Y, Kattge J, Kemp V, Kirkpatrick L, Kleyer M, Correia DLP, Martin CD, Meiri S, Novosolov M, Pan Y, Phillips HRP, Purves DW, Robinson A, Simpson J, Tuck SL, Weiher E, White HJ, Ewers RM, Mace GM, Scharlemann JPW, Purvis A. 2015. Global effects of land use on local terrestrial biodiversity. Nature 520 : 45-50. DOI: 10.1038/nature14324

Pontius Jr RG, Chen H. 2006. GEOMOD modeling. Clark University

Prăvălie R. 2016. Drylands extent and environmental issues. A global approach. Earth-Science Reviews 161 : 259-278. DOI: 10.1016/j.earscirev.2016.08.003

Prishchepov AV, Ponkina E, Sun Z, Müller D. 2019. Revealing the determinants of wheat yields in the Siberian breadbasket of Russia with Bayesian networks. Land Use Policy 80 : 21-31. DOI: 10.1016/j.landusepol.2018.09.038

Reba M, Seto KC. 2020. A systematic review and assessment of algorithms to detect, characterize, and monitor urban land change. Remote Sensing of Environment 242 : 111739. DOI: 10.1016/j.rse.2020.111739

Ridwan MA, Radzi NAM, Ahmad WSHMW, Mustafa IS, Din NM, Jalil YE, Isa AM, Othman NS, Zaki WMDW. 2018. Applications of Landsat-8 Data: a Survey. International Journal of Engineering 83 Technology 7 : 436. DOI: $10.14419 /$ ijet.v7i4.35.22858

Roy DP, Wulder MA, Loveland TR, C.E. W, Allen RG, Anderson MC, Helder D, Irons JR, Johnson DM, Kennedy R, Scambos TA, Schaaf CB, Schott JR, Sheng Y, Vermote EF, Belward AS, Bindschadler R, Cohen WB, Gao F, Hipple JD, Hostert P, Huntington J, Justice CO, Kilic A, Kovalskyy V, Lee ZP, Lymburner L, Masek JG, McCorkel J, Shuai Y, Trezza R, Vogelmann J, Wynne RH, Zhu Z. 2014. Landsat-8: Science and 
product vision for terrestrial global change research. Remote Sensing of Environment145 : 154-172. DOI: 10.1016/j.rse.2014.02.001

Rufin P, Frantz D, Ernst S, Rabe A, Griffiths P, Özdoğan M, Hostert P. 2019. Mapping Cropping Practices on a National Scale Using Intra-Annual Landsat Time Series Binning. Remote Sensing 11 : 232. DOI: $10.3390 /$ rs11030232

Sankey TT, Massey R, Yadav K, Congalton RG, Tilton JC. 2018. Post-socialist cropland changes and abandonment in Mongolia. Land Degradation \& Development 29 : 2808-2821. DOI: 10.1002/ldr.2997

Sekovski I, Mancini F, Stecchi F. 2015. Application of SLEUTH Model to Predict Urbanization Along the Emilia-Romagna Coast (Italy): Considerations and Lessons Learned. In: Gervasi O, Murgante B, Misra S, Gavrilova ML, Rocha AMAC, Torre C, Taniar D and Apduhan BO (eds)Computational Science and Its Applications - ICCSA 2015 . Springer International Publishing: Cham, 426-439. DOI: 10.1007/978-3-31921470-2_31

Soffianian A, Madanian M. 2015. Monitoring land cover changes in Isfahan Province, Iran using Landsat satellite data. Environmental Monitoring and Assessment 187 . DOI: 10.1007/s10661-015-4442-5

Sun P, Xu Y, Yu Z, Liu Q, Xie B, Liu J. 2016. Scenario simulation and landscape pattern dynamic changes of land use in the Poverty Belt around Beijing and Tianjin: A case study of Zhangjiakou city, Hebei Province. Journal of Geographical Sciences 26 : 272-296. DOI: 10.1007/s11442-016-1268-1

The Cambridge History of Iran . 1968. Cambridge University Press. DOI: 10.1017/CHOL9780521069359

Tong X, Brandt M, Hiernaux P, Herrmann SM, Tian F, Prishchepov AV, Fensholt R. 2017. Revisiting the coupling between NDVI trends and cropland changes in the Sahel drylands: A case study in western Niger.Remote Sensing of Environment 191 : 286-296. DOI: 10.1016/j.rse.2017.01.030

Verburg PH, Kok K, Pontius RG, Veldkamp A. 2006. Modeling Land-Use and Land-Cover Change. In: Lambin EF and Geist H (eds) Land-Use and Land-Cover Change. Springer Berlin Heidelberg: Berlin, Heidelberg, 117-135. DOI: 10.1007/3-540-32202-7_5

Verburg PH, Soepboer W, Veldkamp A, Limpiada R, Espaldon V, Mastura SSA. 2002. Modeling the spatial dynamics of regional land use: The CLUE-S model. Environmental Management 30 : 391-405

Wulder MA, Masek JG, Cohen WB, Loveland TR, Woodcock CE. 2012. Opening the archive: How free data has enabled the science and monitoring promise of Landsat. Remote Sensing of Environment 122 : 2-10. DOI: $10.1016 /$ j.rse.2012.01.010

Yaghobi S, Faramarzi M, Karimi H, Sarvarian J. 2019. Simulation of land-use changes in relation to changes of groundwater level in arid rangeland in western Iran. International Journal of Environmental Science and Technology 16 : 1637-1648. DOI: 10.1007/s13762-017-1610-x

Zareie S, Khosravi H, Nasiri A, Dastorani M. 2016. Using Landsat Thematic Mapper (TM) sensor to detect change in land surface temperature in relation to land use change in Yazd, Iran. Solid Earth7 : 1551-1564. DOI: $10.5194 / \mathrm{se}-7-1551-2016$

Zeaiean P, Rabiei HR, Alimohamadi A. 2005. Detection of Land Use/Cover Changes of Isfahan by Agricultural Lands Around Urban Area Using Remote Sensing and GIS Technologies. mdrsjrns 9 : 41-54

Zhang H, Jin X, Wang L, Zhou Y, Shu B. 2015. Multi-agent based modeling of spatiotemporal dynamical urban growth in developing countries: simulating future scenarios of Lianyungang city, China. Stochastic Environmental Research and Risk Assessment 29 : 63-78. DOI: 10.1007/s00477-014-0942-z

Zhao S, Peng C, Jiang H, Tian D, Lei X, Zhou X. 2006. Land use change in Asia and the ecological consequences. Ecological Research21 : 890-896. DOI: 10.1007/s11284-006-0048-2

Table 1: Thematic land-cover and land-use classes. 


\begin{tabular}{ll}
\hline Class & Short description \\
\hline Rocks & Rocky outcrops \\
Rangeland type I & Rangelands with low-density vegetation \\
Rangeland type II & Rangelands with moderate density vegetation \\
Water & Rivers, artificial ponds, wetlands and water channels. \\
Agriculture & Agricultural land used for crops, orchards \\
Forest & Forest, urban and industrial green areas (e.g., parks) \\
Residences & Urban and rural settlements and paved roads \\
Industry & Industrial areas and mines \\
Others & Industrial and mineral wastelands, dirt roads, bare soil \\
\hline
\end{tabular}

Table 2: Accuracy and extent of land use/cover classes (in hectares)

\begin{tabular}{lllllllllll}
\hline & 1985 & 1985 & 1985 & 1985 & 1985 & 1998 & 1998 & 1998 & 1998 & 195 \\
\hline Classes & User's & Producer's & Producer's & Area & Area & User's & Producer's & Producer's & Area & Ar \\
Rocks & 0.49 & 0.77 & 0.77 & 93404 & 93404 & 0.49 & 0.78 & 0.78 & 93253 & 932 \\
Other & 0.41 & 0.87 & 0.87 & 6100 & 6100 & 0.57 & 0.67 & 0.67 & 6230 & 623 \\
Rangeland type I & 0.89 & 0.83 & 0.83 & 314779 & 314779 & 0.88 & 0.81 & 0.81 & 285816 & 285 \\
Rangeland type II & 0.79 & 0.51 & 0.51 & 7089 & 7089 & 0.72 & 0.42 & 0.42 & 3930 & 393 \\
Water & 1 & 0.50 & 0.50 & 969 & 969 & 1 & 0.90 & 0.90 & 1088 & 108 \\
Agriculture & 0.87 & 0.80 & 0.80 & 101595 & 101595 & 0.86 & 0.88 & 0.88 & 123124 & 123 \\
Forest & 0.94 & 0.90 & 0.90 & 654 & 654 & 0.79 & 0.78 & 0.78 & 4138 & 413 \\
Residences & 0.80 & 0.80 & 0.67 & 9498 & 9498 & 0.90 & 0.90 & 0.69 & 0.69 & 147 \\
Industry & 0.76 & 0.76 & 0.81 & 3071 & 3071 & 0.90 & 0.90 & 0.75 & 0.75 & 547 \\
Total accuracy & & & 0.80 & 0.80 & & & & 0.80 & 0.80 & \\
\hline
\end{tabular}

Table 3: Land cover/ use transition matrixes based on classified maps 1985, 1998, and 2016

\begin{tabular}{llll}
\hline Forest & Industry & Residences & $\mathbf{1 9 8 5}$ and $\mathbf{1 9 9 8}$ \\
\hline 232 & 168 & 2775 & Agriculture \\
2760 & 2228 & 1739 & Rangeland type I \\
Forest & Industry & Residences & $\mathbf{1 9 9 8}$ and 2016 \\
8233 & 518 & 4142 & Agriculture \\
2568 & 1439 & 2102 & Rangeland type I \\
\hline
\end{tabular}

\begin{tabular}{ll}
\hline Rangeland to & Rangeland to \\
\hline Residences & Forest \\
$89 \%$ & $87 \%$ \\
Standard Kappa Index Quality Kappa Index Location Kappa Index & Standard Kappa Index Quality Kappa Index Locatio \\
Accuracy of the predicted map 2016 & Accuracy of the predicted map 2016 \\
\hline
\end{tabular}

Table 4: Accuracy of sub-models and prediction model 

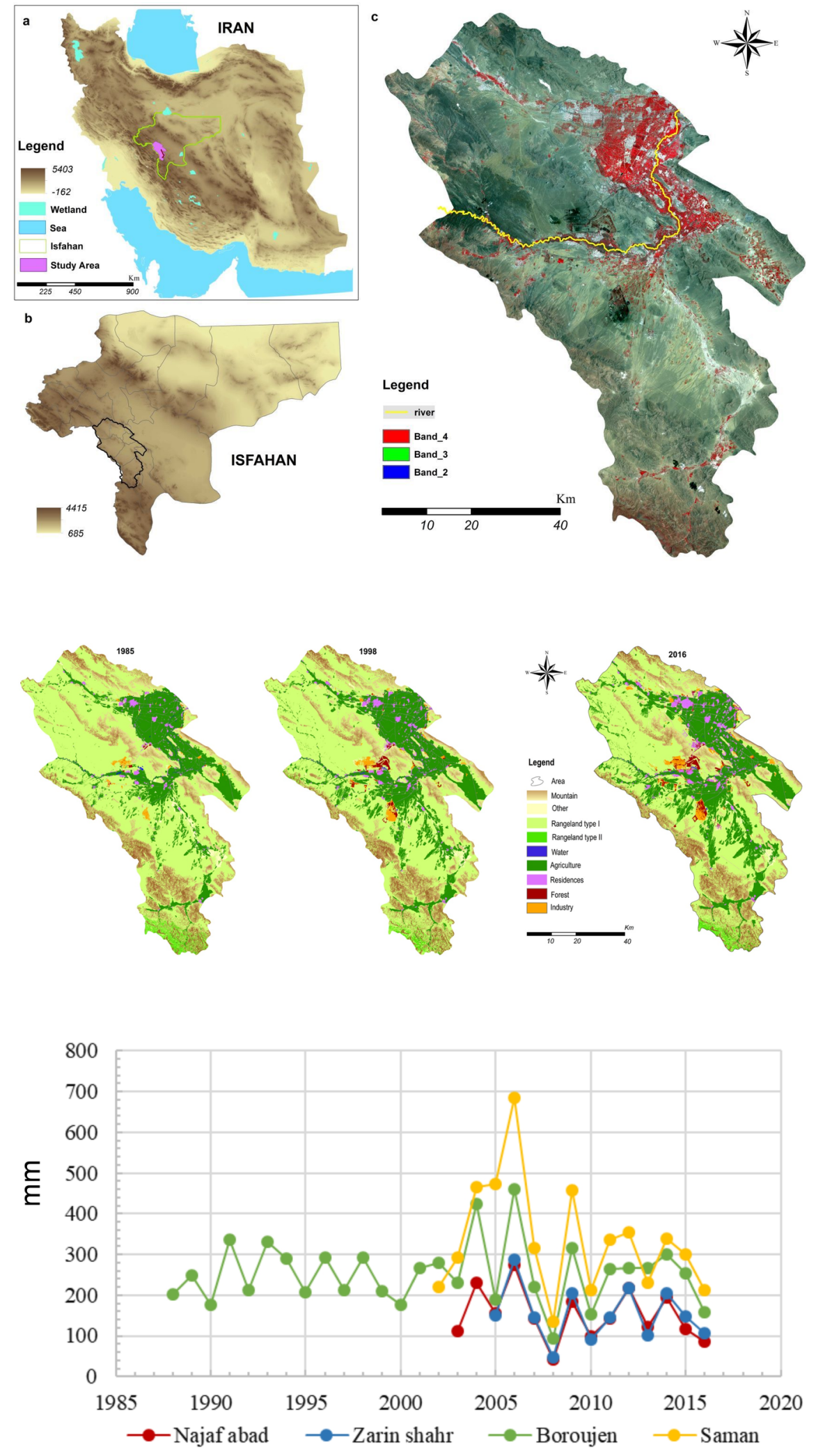

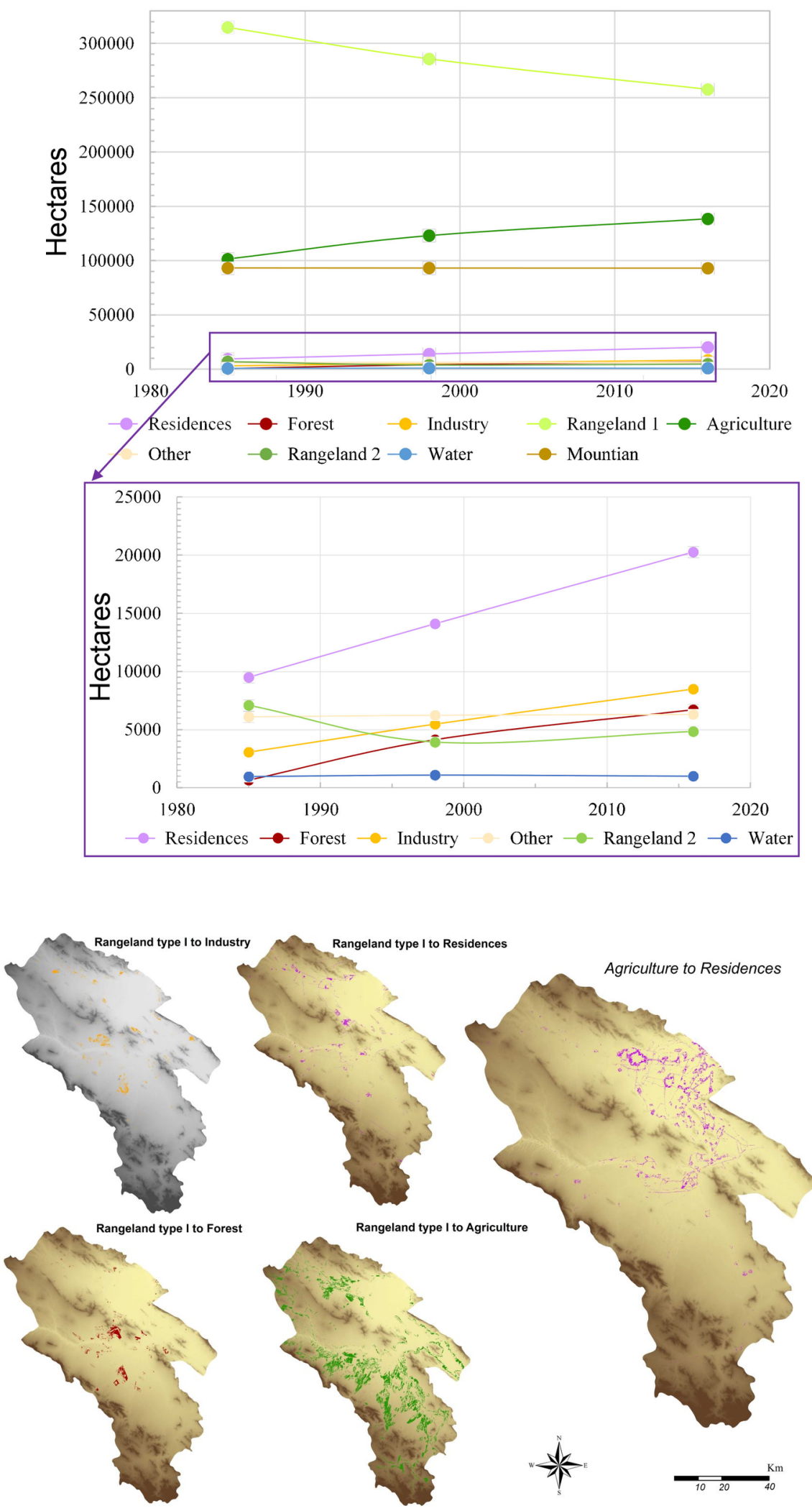

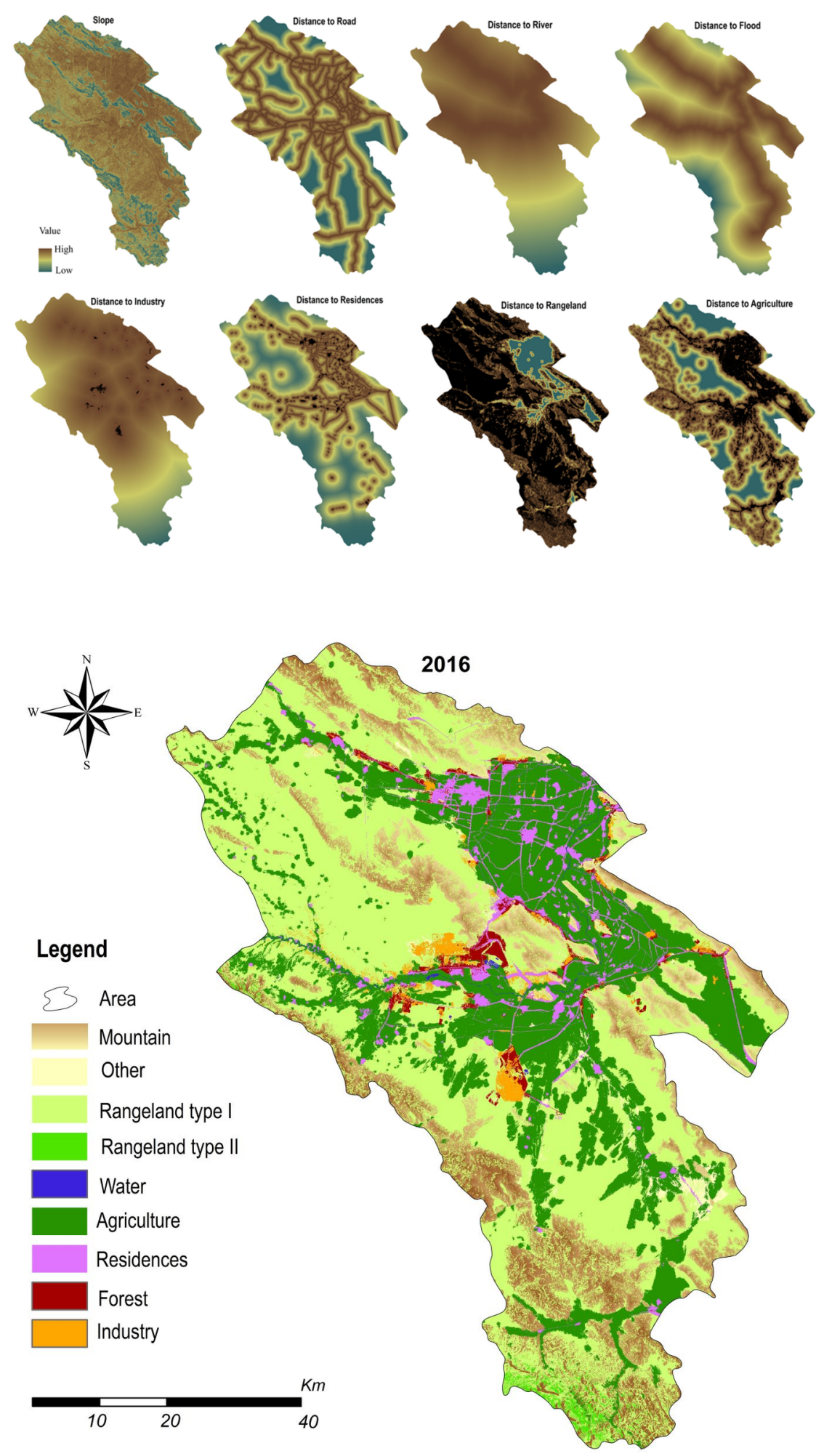

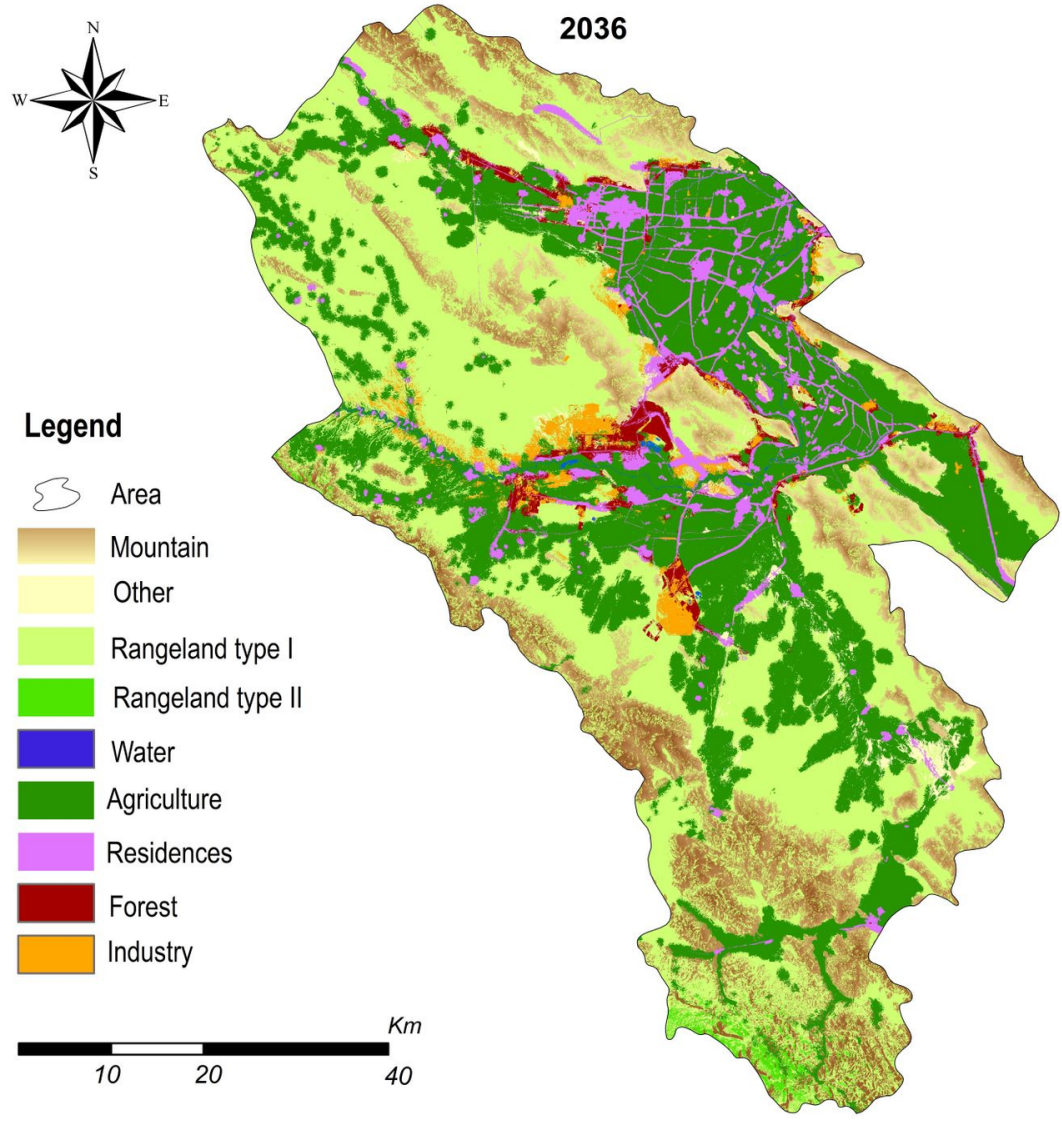

Legend

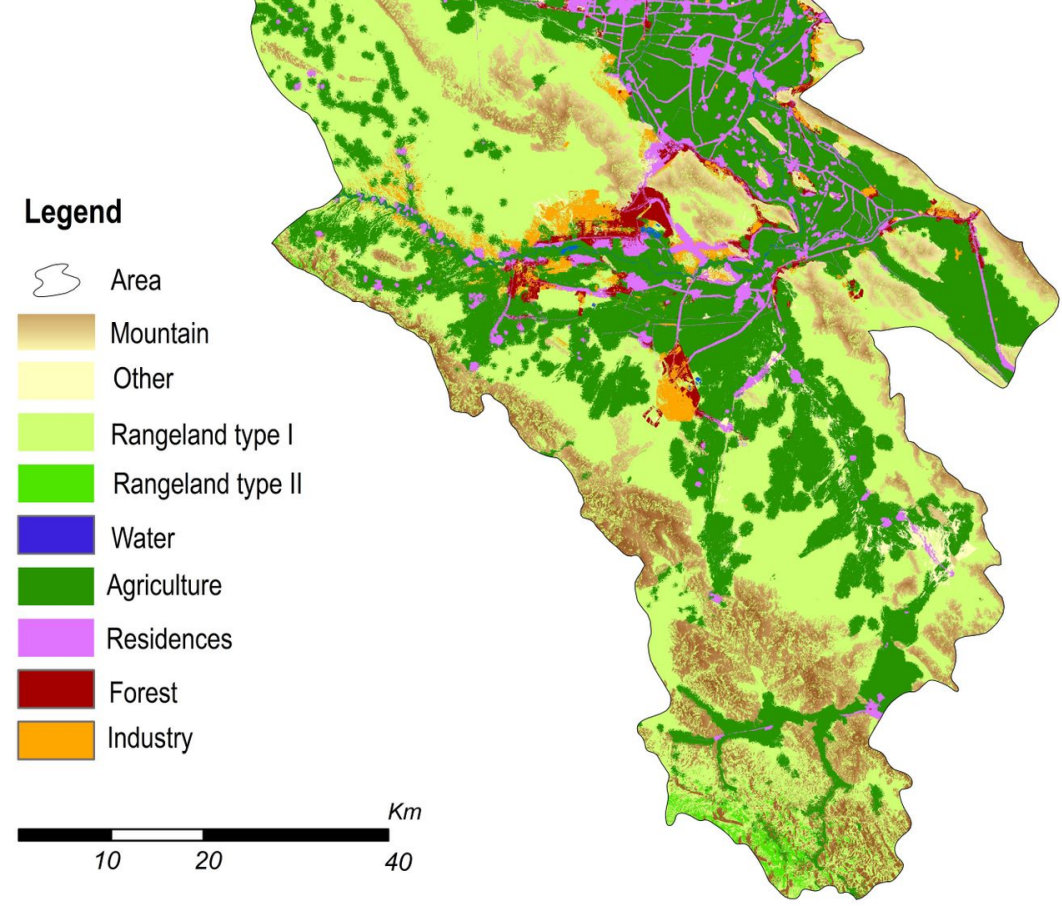

2036 